\title{
Separation and Recovery of Iodine from Aqueous Solution by Permeation and Chemical Desorption (PCD) Using a Silicone Rubber Membrane
}

\author{
Jun Sawai ${ }^{1}$, Hitomi Tomizuka ${ }^{1}$, Naoki Hatanaka ${ }^{1}$, Tamotsu Minami ${ }^{1}$, Mikio Kikuchi ${ }^{1}$, \\ Toshimitsu Ishii ${ }^{2}$ \\ ${ }^{1}$ Faculty of Applied Bioscience, Kanagawa Institute of Technology, Atsugi, Japan \\ ${ }^{2}$ Godo Shigen Sangyo Co., Ltd. Nanaido, Chiba, Japan \\ Email: "sawai@bio.kanagawa-it.ac.jp
}

Received September 5, 2012; revised October 4, 2012; accepted October 12, 2012

\begin{abstract}
New technologies for iodine separation and recovery are required to decrease environmental pollution and improve iodine production. Separation and recovery of iodine $\left(\mathrm{I}_{2}\right)$ in aqueous solution was achieved using permeation and chemical desorption (PCD) with a silicone rubber membrane (SRM). The SRM separated an aqueous feed solution from an alkaline or reducing recovery solution such as a mixture of sodium hydrate and sodium sulfate. The $\mathrm{I}_{2}$ crossed the membrane from the aqueous feed solution into the recovery solution, where it was converted into iodide $\left(\mathrm{I}^{-}\right)$. Iodide in the recovery solution did not return to the feed solution across the SRM. An acidic feed solution promoted a high recovery of iodine. The permeation process followed first-order kinetics, allowing the overall mass-transfer coefficient and parameters related to permeation of $I_{2}$ through the SRM to be determined. Permeability of $I_{2}$ increased with temperature, and the apparent activation energy $\left(E_{\mathrm{a}}\right)$ for penetration of $\mathrm{I}_{2}$ through the SRM was determined. The value of $E_{\text {a }}$ for $\mathrm{I}_{2}$ was of the same order of magnitude as those for phenols and anilines. The large membrane/aqueous distribution coefficient for $I_{2}$ indicated that $I_{2}$ had a high affinity toward the SRM. These results indicate that the PCD method is effective and powerful for separation and recovery of iodine from aqueous solutions.
\end{abstract}

Keywords: Membrane Separation; Permeation and Chemical Desorption (PCD) Method; Diffusion Coefficient; Membrane/Aqueous Distribution Coefficient; Polydimethylsiloxane

\section{Introduction}

Iodine is used in many applications, such as X-ray contrast media [1] and disinfectants [2], because of its high reactivity. Potassium iodide, which is essential to growth, is often added to table salt and feed to prevent iodine deficiency. Iodine and iodine compounds are also used as photo-sensitizers, catalysts, stabilizers, polarizing films on liquid crystal displays, and reaction intermediates [3].

Iodine in brine is usually produced through a blowing-out process [3-5]. The iodine concentration in brine is $60-350 \mathrm{mg} \cdot \mathrm{L}^{-1}(0.2-1.3 \mathrm{mM})$ [6], but the recovery of iodine from brine requires large-scale equipment. The development of new small-scale, energy-saving processes for iodine separation and recovery need to be developed to decrease environmental pollution and improve iodine production.

The membrane separation process is widely used in industry because it offers several advantages, such as low

*Corresponding author. energy consumption, low space use, and simple process design, compared to other processes [7,8]. The permeation and chemical desorption (PCD) method has been proposed as an alternative method for iodine recovery $[9,10]$. A target substance can be separated and recovered from an aqueous solution by altering the characteristics of the substance from high affinity toward the membrane to poor affinity by a chemical reaction, such as neutralization or oxidation-reduction. A previous study [11] explored the separation and recovery of 4-substituted phenol and aniline derivatives from aqueous solutions using PCD with a silicone rubber membrane (SRM). Phenols or anilines in aqueous solution were recovered successfully into aqueous $\mathrm{NaOH}$ or $\mathrm{HCl}$ solutions, respectively. A comparison between PCD and pervaporation (PV) was performed, which revealed that the removal rate of phenols from aqueous solution by PCD was significantly greater than by PV, and showed that PCD is effective for separation and recovery of low-volatility compounds $[12,13]$. Ferreira et al. proposed a recovery system for 
phenols and anilines using an SRM as a membrane aromatic recovery system (MARS) and reported success of a pilot-scale plant [14,15].

Iodine is attracted to the hydrophobic silicone membrane because of its high solubility in organic solvents, offering the ability to separate it by PCD. Thus, a project was undertaken to recover iodine and its derivatives that had been released into the environment and to improve iodine production by PCD using an SRM $[9,10]$. In this study, we tried to apply the PCD method for separation of iodine from water and obtained the recovery conditions and parameters for permeation of $\mathrm{I}_{2}$ to the SRM. We have showed that the PCD method was effective and powerful for separation and recovery of iodine from aqueous solutions and the possibility of the PCD method to simplify the production of iodine and reduce energy consumption and space needs in this paper.

\section{Materials and Methods}

\subsection{Permeation Experiment}

The apparatus used for PCD was the same as described previously [11]. The SRM (As One Co., Ltd., Osaka, Japan) was inserted between two glass cells (capacity: $250 \mathrm{~mL}$ ) and was fixed by flanges. The thickness of the SRM varied from 0.05 to $0.3 \mathrm{~mm}$, with an effective area of $1.5 \times 10^{-3} \mathrm{~m}^{2}$. The SRM was made of polydimethylsiloxane and fumed silica, which was confirmed using attenuated total reflectance Fourier-transform infrared spectroscopy (data not shown). An iodine (Kanto Kagaku Co., Ltd., Tokyo, Japan) solution was prepared at a concentration of 0.8 mmol- $\mathrm{I}_{2} \mathrm{~L}^{-1}$ in distilled water. The $\mathrm{pH}$ of the iodine solution was adjusted using $\mathrm{HCl}$ and $\mathrm{NaOH}$ solutions. The iodine solution $(250 \mathrm{~mL})$ was added into the feed side cell. The composition of the solutions (250 $\mathrm{mL}$ ) assayed on the recovery side is shown in Table $\mathbf{1 .}$ The two solutions were agitated using a magnetic stirrer. Samples $(1 \mathrm{~mL})$ were withdrawn from both cells at regular intervals, and the iodine and iodide concentrations on each side solution were determined as described below. The experimental temperature $\left(15^{\circ} \mathrm{C}-45^{\circ} \mathrm{C}\right)$ was controlled using a water bath.

\subsection{Determination of Iodine or Iodide Concentration}

High performance liquid chromatography (HPLC) using a UV detector measured the concentration of iodine. Volumes of $0.1 \mathrm{~mL}$ sodium sulfite solution $\left(0.5 \mathrm{~mol} \cdot \mathrm{L}^{-1}\right)$ and $0.5 \mathrm{~mL}$ of acetic acid buffer solution $\left(0.2 \mathrm{~mol} \cdot \mathrm{L}^{-1}\right)$ were added to $1 \mathrm{~mL}$ of the sample solution. This mixture was analyzed to determine iodide concentration under the conditions shown in Table 2. All reagents were analyticcal grade purchased from Kanto Kagaku Co., Ltd. (Tokyo, Japan).

\subsection{Measurement of Membrane Distribution Coefficient of $\mathbf{I}_{2}$}

An SRM $(20 \times 20 \mathrm{~mm})$ with a thickness of $0.05 \mathrm{~mm}$ was immersed for $24 \mathrm{~h}$ in a bottle containing $10 \mathrm{~mL}$ of fresh iodine solution at 0.80 or $1.6 \mathrm{mmol}-\mathrm{I}_{2} \mathrm{~L}^{-1}$ at $\mathrm{pH} 4.0$, and the equilibrium iodine concentration $\left(C_{\mathrm{E} 1}\right)$ was determined by using the HPLC as described above. The SRM was removed from the solution, drained, and immersed in $20 \mathrm{mmol} \cdot \mathrm{L}^{-1} \mathrm{NaOH}$. After $24 \mathrm{~h}$, the concentration of iodide released from the SRM in the $\mathrm{NaOH}$ solution $\left(C_{\mathrm{E} 2}\right)$ was determined. The membrane distribution coefficient, $m_{\mathrm{c}}$, was estimated based on the values of $C_{\mathrm{E} 1}$ and $C_{\mathrm{E} 2}$. The equilibrium experiments were performed at $25^{\circ} \mathrm{C}$.

Each experiment was conducted 3 times and average value was shown as a result; the $\mathrm{SE}$ of the average value remained below $15 \%$.

\section{Results and Discussion}

\section{1. pH Dependency of Iodine Permeation through SRM}

The permeation of iodine through SRM was investigated using $\mathrm{NaOH}$ solution in the recovery at different $\mathrm{pH}$ values of the iodine solution in the feed cell. Figure 1 shows the permeation ratio, $R_{p}$, at different feed cell $\mathrm{pH}$ values after $5 \mathrm{~h}$. The SRM thickness was $0.05 \mathrm{~mm}$, and temperature was $25^{\circ} \mathrm{C}$. $R_{\mathrm{P}}$ was obtained using Equation (1):

Table 1. Overall mass transfer coefficients $\left(K_{\mathrm{OL}}\right)$ of iodine for several recovery solutions.

\begin{tabular}{|c|c|c|c|}
\hline \multirow{2}{*}{ Reagents } & \multicolumn{2}{|c|}{ Concentration $\left(\mathrm{mmol} \cdot \mathrm{l}^{-1}\right)$} & \multirow{2}{*}{$K_{\mathrm{OL}} \times 10^{5}\left(\mathrm{~m} \cdot \mathrm{s}^{-1}\right)$} \\
\hline & $\mathrm{Na}_{2} \mathrm{CO}_{3}$ & $\mathrm{Na}_{2} \mathrm{SO}_{3}$ & \\
\hline \multirow[t]{4}{*}{$\mathrm{Na}_{2} \mathrm{CO}_{3}+\mathrm{Na}_{2} \mathrm{SO}_{4}{ }^{*}$} & 1 & 1 & 0.95 \\
\hline & 10 & 10 & 1.2 \\
\hline & 50 & 50 & 1.3 \\
\hline & 100 & 100 & 1.2 \\
\hline
\end{tabular}

${ }^{*} \mathrm{Na}_{2} \mathrm{CO}_{3}$ and $\mathrm{Na}_{2} \mathrm{SO}_{3}$ are equimolar.

Table 2. HPLC measurement conditions.

\begin{tabular}{|c|c|}
\hline Model & LC-6A (Shimadzu Co, Kyoto, Japan) \\
\hline \multirow[t]{2}{*}{ Detector } & $\begin{array}{l}\text { UV spectrophotometric detector SPD-6A } \\
\text { (Shimidzu Co.) }\end{array}$ \\
\hline & $220 \mathrm{~nm}$ \\
\hline Column & $\begin{array}{l}\text { Luna } 5 \mathrm{~m} \mathrm{C18}, 150 \mathrm{~mm} \times 4.6 \mathrm{~mm} \\
\text { (Phenomenex, CA, USA) }\end{array}$ \\
\hline Column temperature & $40^{\circ} \mathrm{C}$ \\
\hline \multirow[t]{2}{*}{ Mobile phase } & $\begin{array}{l}\mathrm{CH}_{3} \mathrm{CN} / \mathrm{H}_{2} \mathrm{O}-20 \mathrm{mmol} \cdot \mathrm{l}^{-1} \\
\text { tetrabutylammonium phosphate }=25 / 75\end{array}$ \\
\hline & (Kanto Kagaku Co., LTD., Tokyo, Japan) \\
\hline Flow rate & $1.0 \mathrm{ml} \cdot \mathrm{min}^{-1}$ \\
\hline Injection volume & $10 \mathrm{ml}$ \\
\hline
\end{tabular}




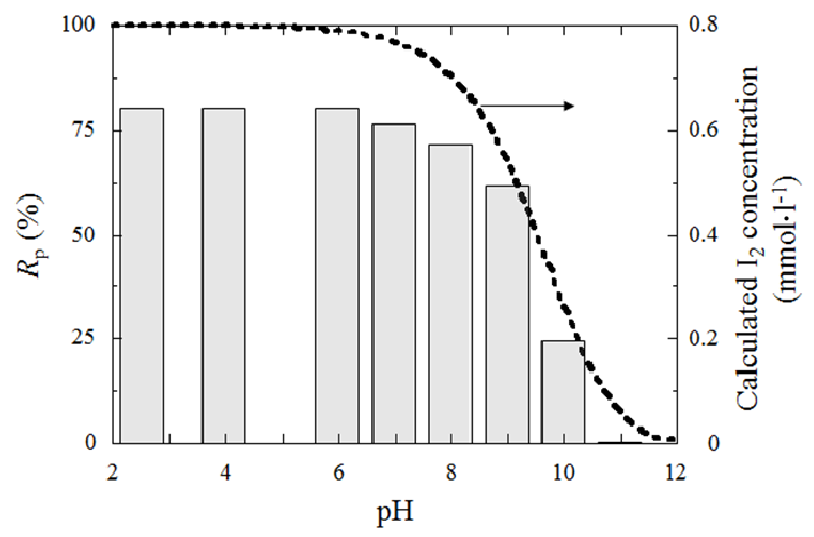

Figure 1. The percentage of iodine permeated through theSRM after $5 \mathrm{~h}$ and theoretically calculated effective $I_{2}$ concentration at different $\mathbf{p H}$ values. (Recovery cell: 10 $\mathrm{mmol} \cdot \mathrm{L}^{-1} \mathrm{NaOH}$; membrane thickness: $0.05 \mathrm{~mm}$; temperature: $25^{\circ} \mathrm{C}$ ).

$$
R_{p}(\%)=\frac{C_{0}-C}{C_{0}} \times 100
$$

where $C_{0}$ and $C$ are the initial iodine concentration and the concentration at time $t$, respectively, in the feed cell. The value of $R_{p}$ remained constant up to $\mathrm{pH} 6$, and $80 \%$ of the iodine migrated to the recovery side after $5 \mathrm{~h}$. The value of $R_{p}$ decreased with an increase in $\mathrm{pH}$, and no permeation was observed at $\mathrm{pH} 11$.

Iodine hydrolyzes in aqueous solution as described by Equation (2), and the hydrolysis constant, $K_{h}$, is expressed by Equation (3) $[16,17]$ :

$$
\begin{gathered}
\mathrm{I}_{2}+\mathrm{H}_{2} \mathrm{O} \rightleftarrows \mathrm{HIO}+\mathrm{H}^{+}+\mathrm{I}^{-}, \\
K_{h}=\frac{[\mathrm{HIO}]\left[\mathrm{H}^{+}\right]\left[\mathrm{I}^{-}\right]}{\left[\mathrm{I}_{2}\right]}=4.6 \times 10^{-13}\left(\mathrm{~mol} \cdot \mathrm{l}^{-1}\right)^{2}\left(25^{\circ} \mathrm{C}\right)
\end{gathered}
$$

Equation (3) demonstrates that $\mathrm{pH}$ strongly influences the chemical equilibrium of $\mathrm{I}_{2}$ and $\mathrm{I}^{-}$in aqueous solution. The effective $\mathrm{I}_{2}$ concentration calculated based on Equations (2) and (3) are shown as a dotted line in Figure 1. Here, the contribution of dismutation reaction of $\mathrm{HIO}$ in water $\left(2 \mathrm{HIO} \rightleftarrows 2 \mathrm{HI}+\mathrm{O}_{2}\right.$ and $3 \mathrm{HIO} \rightleftarrows \mathrm{HIO}_{3}+2 \mathrm{HI}$ ) was neglected to simplify the analysis. Figure 1 shows that the variation in $R_{p}$ correlated with that of the calculated effective $\mathrm{I}_{2}$ concentration. These results indicate that $\mathrm{I}_{2}$ can be adsorbed in, dissolve in and penetrate through the SRM, but I' cannot (Figure 2). Iodide ion with the negative charge is difficult to be adsorbed in SRM, because the SRM is a hydrophobic membrane. Thus, placing iodine in an acidic solution in the feed cell, with an alkaline solution in the recovery cell, is efficient for recovery of iodine. This system also can concentrate iodine on the recovery side, because $\mathrm{I}^{-}$in the recovery cell cannot return to the feed side through the SRM.

\subsection{Absorbent Solution in Recovery Cell}

The type of absorbent solution in the recovery cell for $\mathrm{I}_{2}$ was investigated. Figure 3 shows typical changes in $\mathrm{I}_{2}$ concentration in the feed solution. Iodine concentration in the feed cell decreased with time. Iodine and iodide concentration measurements on both sides showed that a mass balance was established in this system. Stripping of $\mathrm{I}_{2}$ and absorption by the alkaline recovery solution occur simultaneously in this system. Thus, $\mathrm{I}_{2}$ concentration on the recovery side can be considered to be zero $\left(\mathrm{I}_{2} \rightarrow 2 \mathrm{I}^{-}\right)$, and the $\mathrm{I}_{2}$ concentration on the feed side $(C)$ can be represented by $[18,19]$ :

$$
\ln \frac{C}{C_{0}}=-\frac{A}{V} K_{\mathrm{OL}} t
$$

where $A$ and $V$ are the effective membrane area and the liquid volume in the feed cell, respectively. $K_{\mathrm{OL}}$ is the overall mass transfer coefficient.

As shown in Figure 3, $\ln \left(C / C_{0}\right)$ was proportional to $t$. A similar tendency was observed under other conditions,

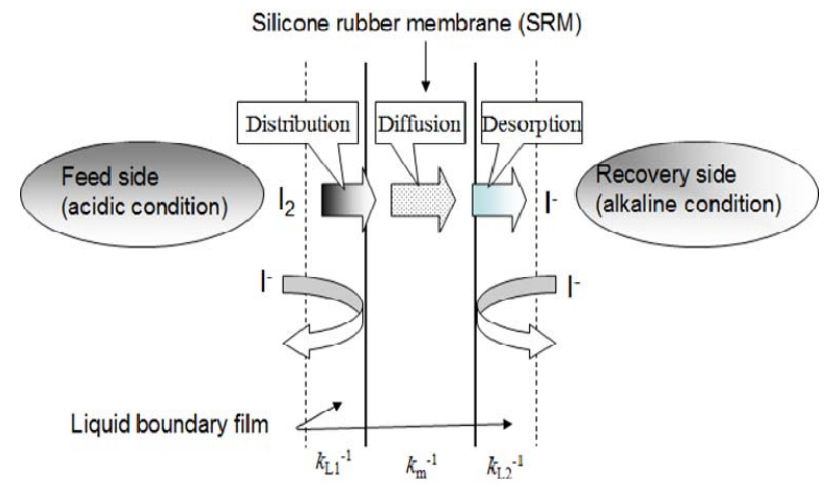

Figure 2. Model of permeation of $I_{2}$ through the SRM for the PDC method.

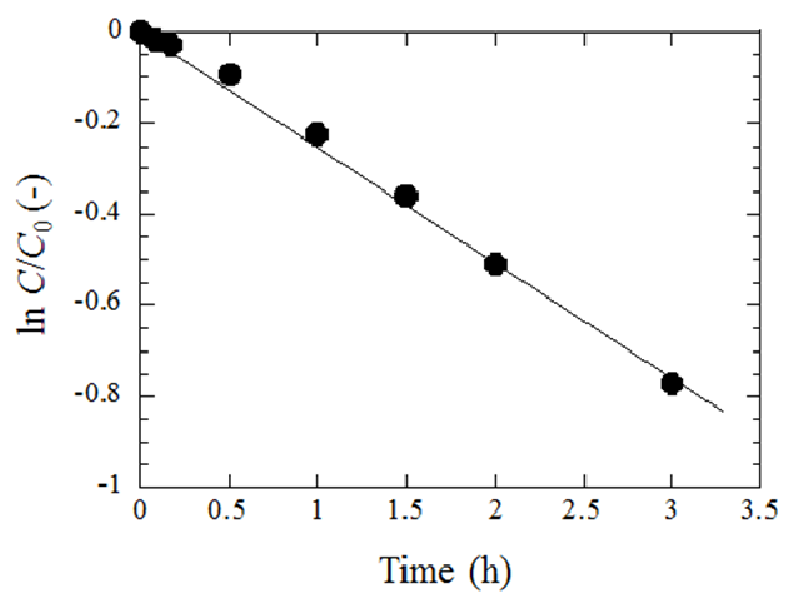

Figure 3. Typical permeation of iodine through the SRM. (Feed cells: 0.8 mmol $\mathrm{I}_{2} \mathrm{~L}^{-1}$ solution at $\mathrm{pH}$ 4.0; recovery cell: $10 \mathrm{mmol} \cdot \mathrm{L}^{-1} \mathrm{Na}_{2} \mathrm{CO}_{3}+\mathrm{Na}_{2} \mathrm{SO}_{3}$; membrane thickness: 0.05 $\mathrm{mm}$; temperature: $25^{\circ} \mathrm{C}$ ). 
allowing determination of $K_{\mathrm{OL}}$ from the slope of the line (Table 1). A solution of $\mathrm{Na}_{2} \mathrm{SO}_{3}+\mathrm{Na}_{2} \mathrm{CO}_{3}$ was used in the blowing-out process for recovery of iodine [3]. Values of $K_{\mathrm{OL}}$ for the $\mathrm{Na}_{2} \mathrm{SO}_{3}+\mathrm{Na}_{2} \mathrm{CO}_{3}$ solution at concentrations greater than $10 \mathrm{mmol} \cdot \mathrm{L}^{-1}$ became constant $(1.2$ $1.3 \mathrm{~m} \cdot \mathrm{s}^{-1}$ ); this constant value was similar to that for 10 $\mathrm{mmol} \cdot \mathrm{L}^{-1} \mathrm{NaOH}$. Thus, $10 \mathrm{mmol} \cdot \mathrm{L}^{-1} \mathrm{Na}_{2} \mathrm{SO}_{3}+\mathrm{Na}_{2} \mathrm{CO}_{3}$ was used as the absorbent solution in the recovery cell, because its $\mathrm{pH}$ (11.1), was lower than that of 10 $\mathrm{mmol} \cdot \mathrm{L}^{-1} \mathrm{NaOH}(\mathrm{pH} 12)$. The PCD method does not need a phase change such as liquid to vapourin the blowing-out process and pressure operation basically. It can be said to be an excellent technique in energy saving.

\subsection{Permeation Characteristics of $I_{2}$ into the SRM}

The resistances-in-series model has been used to describe the transport of molecules through a membrane with liquid films on both sides (Figure 2). The term $1 / K_{\mathrm{OL}}$ represents overall mass transfer resistance and can be written as:

$$
\frac{1}{K_{\mathrm{OL}}}=\frac{1}{k_{\mathrm{L} 1}}+\frac{1}{m_{\mathrm{c}} k_{\mathrm{m}}}+\frac{1}{k_{\mathrm{L} 2}}
$$

where $k_{L 1}$ and $k_{L 2}$ are the liquid boundary film mass transfer coefficients of the feed and recovery sides, respectively, and $k_{\mathrm{m}}$ and $m_{\mathrm{c}}$ are the mass transfer coefficient in the membrane and membrane/aqueous distribution coefficient, respectively. When chemical absorption occurs as described, the mass transfer resistance of the recovery side $\left(k_{\mathrm{L} 2}{ }^{-1}\right)$ is negligible $[18,19]$, and $k_{\mathrm{m}}$ relates to diffusivity, $D$, and film membrane thickness, $d$, as shown by Equation (6):

$$
k_{\mathrm{m}}=D / d
$$

Equation (6) can be re-written as:

$$
\frac{1}{K_{\mathrm{OL}}}=\frac{1}{k_{\mathrm{L} 1}}+\frac{d}{m_{\mathrm{c}} D}=\frac{1}{k_{\mathrm{L} 1}}+\frac{d}{P}
$$

where $P=m_{c} D$. Equation (7) describes a linear relation between $d$ and $1 / K_{\mathrm{OL}}$. The value of $P$ can be obtained from the slope of the line and the $D$ values can be estimated using the $m_{c}$ values obtained in Section 2.3.

Figure 4 shows changesin the $K_{\mathrm{OL}}$ of $\mathrm{I}_{2}$ with SRM thickness $(d)$. The value for $1 / K_{\mathrm{OL}}$ increased linearly with $d$. The value of $D$ was estimated by inserting experimenttally determined $m_{\mathrm{c}}$ values into the expression for $P$. The value of $\log m_{\mathrm{c}}$ was 3.7 and did not change with $\mathrm{I}_{2}$ concentration. Table 3 summarizes the values of octanol/ water partition coefficient $\left(P_{\mathrm{OW}}\right), m_{\mathrm{c}}$, and $D$ obtained for $\mathrm{I}_{2}$ in this study, along with the values for phenols and anilines obtained previously [12]. Iodine $\left(\mathrm{I}_{2}\right)$ has larger values for $m_{\mathrm{c}}$ than for $P_{\mathrm{OW}}$, indicating a high affinity of $\mathrm{I}_{2}$ toward the SRM, which indicates the effectiveness of the SRM for the separation and recovery of iodine.

The $D$ value of $\mathrm{I}_{2}$ was smaller than those of phenols and anilines, despite the smaller molar volume of $\mathrm{I}_{2}$. Watanabe and Miyauchi measured the solubility and diffusivity of $\mathrm{I}_{2}$ in polydimethylsiloxane oils and organic solvents, and reported that the diffusivity of $\mathrm{I}_{2}$ in polydimethylsiloxane did not change with the polymer chain length. They attributed this phenomenon to the

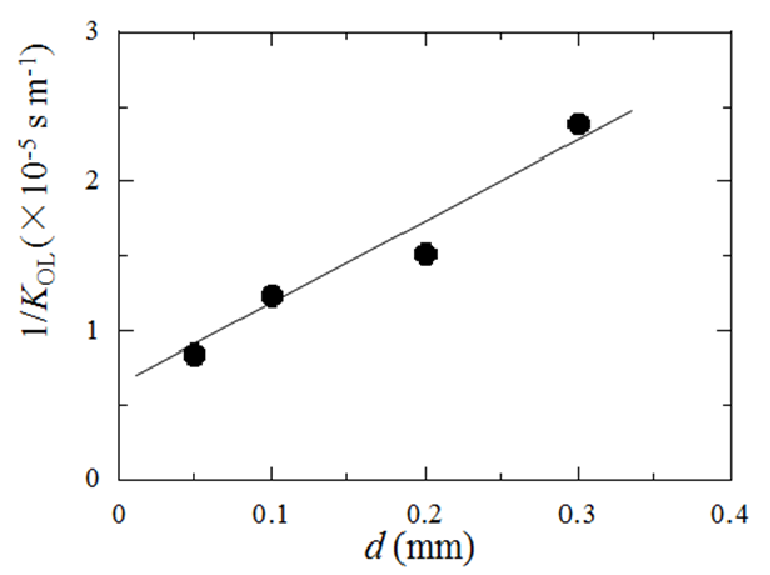

Figure 4. Effect of SRM thickness on the overall mass transfer coefficient $\left(K_{\mathrm{OL}}\right)$ of iodine. (Feed cells: $0.8 \mathrm{mmol} \mathrm{I}_{2}$ $\mathrm{L}^{-1}$ at pH 4.0; recovery cell: $10 \mathrm{mmol} \cdot \mathrm{L}^{-1} \mathrm{Na}_{2} \mathrm{CO}_{3}+\mathrm{Na}_{2} \mathrm{SO}_{3}$,

\begin{tabular}{|c|c|c|c|c|c|c|c|}
\hline Chemicals & $\begin{array}{c}\text { Molecular weight } \\
\left(\mathrm{g} \cdot \mathrm{mol}^{-1}\right)\end{array}$ & $\begin{array}{c}\text { Molar volume } \\
\left(\mathrm{ml} \cdot \mathrm{mol}^{-1}\right)\end{array}$ & $\begin{array}{c}\log P_{\mathrm{OW}} \\
(-)\end{array}$ & $\begin{array}{c}\log m_{\mathrm{C}} \\
(-)\end{array}$ & $\begin{array}{c}D \\
\times 10^{10}\left(\mathrm{~m}^{2} \cdot \mathrm{s}^{-1}\right)\end{array}$ & $\begin{array}{c}E_{\mathrm{a}} \\
\left(\mathrm{kJ} \cdot \mathrm{mol}^{-1}\right)\end{array}$ & Reference \\
\hline $\mathrm{I}_{2}{ }^{*}$ & 253.8 & 51.4 & $2.49^{\mathrm{a}}$ & 3.7 & 0.11 & 41.9 & \\
\hline Phenol & 94.1 & 88.6 & 1.5 & -0.30 & 1.46 & $17^{\mathrm{b}}$ & \\
\hline 4-Cresol & 108.1 & 104.5 & 1.9 & 0.36 & 2.43 & & [12] \\
\hline 4-Butylphenol & 150.2 & 166.5 & 3.8 & 2.02 & 0.12 & & \\
\hline Aniline & 93.1 & 90.7 & $0.94^{\mathrm{c}}$ & $0.56^{\mathrm{d}}$ & $1.2^{\mathrm{d}}$ & 18.1 & \\
\hline 4-Chloroaniline & 127.6 & 89.2 & $1.8^{\mathrm{e}}$ & & & 15.6 & [22] \\
\hline Dimethylamine & 45.1 & 64.4 & $2.3^{f}$ & & & 30.5 & \\
\hline
\end{tabular}
temperature: $25^{\circ} \mathrm{C}$ ).

Table 3. Parameters of compounds tested for affinity toward a silicone rubber membrane.

*This work; ${ }^{\mathrm{a} I n t e r n a t i o n a l ~ C h e m i c a l ~ S a f e t y ~ C a r d s ~(I C S C s) ~ N o . ~ 0167 ; ~}{ }^{\mathrm{b}}$ [22]; ${ }^{\mathrm{C} I n t e r n a t i o n a l ~ C h e m i c a l ~ S a f e t y ~ C a r d s ~(I C S C s) ~ N o . ~ 0011 ; ~}{ }^{\mathrm{d}}$ [12]; ${ }^{\mathrm{e} I n t e r n a t i o n a l}$ Chemical Safety Cards (ICSCs) No. 0026; International Chemical Safety Cards (ICSCs) No. 0877. 


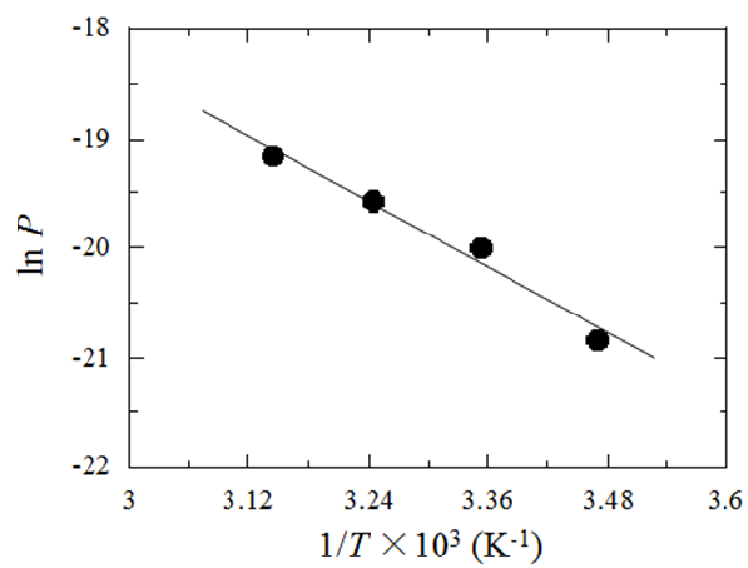

Figure 5. Effect of temperature on permeability $(P)$ of $I_{2}$ through the SRM. (Feed cells: $0.8 \mathrm{mmol} \mathrm{I}_{2} \mathrm{~L}^{-1}$ solutionat $\mathrm{pH}$ 4.0; recovery cell: $10 \mathrm{mmol} \cdot \mathrm{L}^{-1} \mathrm{Na}_{2} \mathrm{CO}_{3}+\mathrm{Na}_{2} \mathrm{SO}_{3}$; membrane thickness: $0.2 \mathrm{~mm}$ ).

$20 \%-30 \%$ larger size of the siloxane unit [-OSi(Me $)_{2}$ compared to $\mathrm{I}_{2}$, which did not change with increasing polymer chain length [20]. Therefore, the small $D$ value of $I_{2}$ regardless small molar weight will depend on the siloxane unit size.

Figure 5 shows variation in $P$ values with temperature (SRM thickness: $0.2 \mathrm{~mm}$ ). The value of $P$ increased with temperature, due to temperature-enhanced mobility of the polymer chains that allow the penetrant to diffuse more easily. According to molecular models for rubbery polymers above their glass transition temperatures, the temperature dependence of $P$ of the penetrant through a polymer follows the van't Hoff-Arrhenius relation [21]:

$$
P=P_{0} \exp \left(-\frac{E_{\mathrm{a}}}{R T}\right)
$$

where $P_{0}$ is a pre-exponential factor, $R$ is the molar gas constant, $T$ is the absolute temperature, and $E_{\mathrm{a}}$ is the apparent activation energy of penetration required for sorption of the penetrant into polymers. Higher $E_{\mathrm{a}}$ values indicate that additional energy is needed for the penetrant to permeate through the polymer.

The value of $E_{\mathrm{a}}$ for $\mathrm{I}_{2}$ to the SRM was obtained from Equation (8) (Table 3). Compared with the $E_{\mathrm{a}}$ values of phenols [22] and aniline [23], the $E_{\mathrm{a}}$ of $\mathrm{I}_{2}$ was the same order of magnitude, suggesting that thermal activity also is effective for the separation and recovery of $\mathrm{I}_{2}$ using PCD.

Although this technique is applicable to various compounds except iodine [9-13], the recovery of the substance, which is ionized in the recovery side, is theoreticcally difficult. It is necessary to also challenge separation of such a substance and to extend the scope of application.

\section{Conclusion}

In this study, permeation and chemical desorption (PCD) using a silicone rubber membrane (SRM) was effective and powerful for the separation and recovery of iodine. The $I_{2}$ had high affinity toward the SRM. The $I_{2}$ in aqueous solution was recovered into an alkaline or $\mathrm{Na}_{2} \mathrm{SO}_{3}+\mathrm{Na}_{2} \mathrm{CO}_{3}$ recovery solution by placing iodine solution and alkali or $\mathrm{Na}_{2} \mathrm{SO}_{3}+\mathrm{Na}_{2} \mathrm{CO}_{3}$ solution on opposite sides of an SRM. Higher recovery of $\mathrm{I}_{2}$ was obtained by controlling the $\mathrm{pH}$ of the feed solution. This PCD method cansimplifythe production of iodine and reduce energy consumption and space needs. Iodine can be obtained as a solid after neutralization from the recovery solution. An initial pilot study for recovery of iodine and iodides has been initiated using a silicone hollow-fiber membrane manufactured from the same silicone rubber used in this work. In a continuous experiment using the membrane, no change was found in the recovery rate of iodine over one month (data not shown), indicating adequate lifespan of the silicone membrane. We propose this method as an alternative to the blowing-out process for separation of iodine.

\section{REFERENCES}

[1] B. Aydogan, J. L. TijanaRajh, A. Chaudhary, S. J. Chmura, C. Pelizzari, C. Wietholt, M. Kurtoglu and P. Redmond, “AuNP-DG: Deoxyglucose-Labeled Gold Nanoparticles as X-Ray Computed Tomography Contrast Agents for Cancer Imaging," Molecular Imaging and Biology, Vol. 12, No. 5, 2010, pp. 463-467. doi:10.1007/s11307-010-0299-8

[2] J. Luo, Y. Deng and Y. Sun, "Antimicrobial Activity and Biocompatibility of Polyurethane-Iodine Complexes," Journal of Bioactive and Compatible Polymers, Vol. 25, No. 2, 2010, pp. 185-206

[3] P. A. Lyday, “Iodine,” In: US Geological Survey Minerals Yearbook-1999, US Geological Survey Publications, Reston, 1999.

[4] S. Sunagawa, "History of Iodine Production," Journal of the Japanese Society for the History of Chemistry, Vol. 24, No. 4, 1997, pp. 281-294. (In Japanese)

[5] F. C. Küpper, M. C. Feiters, B. Olofsson, T. Kaiho, S. Yanagida, M. B. Zimmermann, L. J. Carpenter, G. W. Luther, Z. Lu, Z., M. Jonsson and L. Kloo, "Commemorating Two Centuries of Iodine Research: An Interdisciplinary Overview of Current Research,” Angewandte Chemie International Edition, Vol. 50, No. 49, 2011, pp. 11598-11620. doi:10.1002/anie.201100028

[6] I. Mita, Y. Hioguchi and T. Hoguchi, "Concentration Mechanisms of Iodine Contained in Brine," Bulletin of the Society of Sea Water Science, Japan, Vol. 60, No. 2, 2006, pp. 91-97.

[7] J. B. Snape and M. Nakajima, "Processing of Agricultural Fats and Oils Using Membrane Technology,” Journal of Food Engineering, Vol. 30, No. 1, 1996, pp. 1-41. doi:10.1016/S0260-8774(96)00053-2

[8] M. T. Ravanchi, T. Kaghazchi and A. Kargari, “Applica- 
tion of Membrane Separation Processes in Petrochemical Industry: A Review,” Desalination, Vol. 235, No. 1-3, 2009, pp. 199-244. doi:10.1016/j.desal.2007.10.042

[9] M. Kikuchi, K. Sato and T. Minami, JP Patent 2001293472, 2001.

[10] M. Kikuchi, K. Sato and T. Minami, JP Patent 2002331228, 2002.

[11] J. Sawai, N. Ito, T. Minami and M. Kikuchi, "Separation of Low Volatile Organic Compounds, Phenol and Aniline Derivatives, from Aqueous Solution Using Silicone Rubber Membrane,” Journal of Membrane Science, Vol. 252, No. 1-2, 2005, pp. 1-7. doi:10.1016/j.memsci.2004.06.018

[12] J. Sawai, K. Higuchi, T. Minami and M. Kikuchi, "Removal and Permeation Characteristics of 4-Substituted Phenol and Aniline Derivatives in Aqueous Solution Using a Silicone Rubber Membrane,” Chemical Engineering Journal, Vol. 152, No. 1, 2009, pp. 133-138. doi:10.1016/j.cej.2009.04.003

[13] J. Sawai, K. Sahara, T. Minami and M. Kikuchi, "Separation of Pentachlorophenol in Aqueous Phase by Silicone Rubber Membrane," Advances in Chemical Engineering and Science, Vol. 2, No. 3, 2012, pp. 372-378. doi:10.4236/aces.2012.23044

[14] F. C. Ferreira, S. Han and A. G. Livingston, "Recovery of Aniline from Aqueous Solution Using the Membrane Aromatic Recovery System,” Industrial \& Engineering Chemistry Research, Vol. 41, No. 11, 2002, pp. 27662774. doi:10.1021/ie010746l

[15] F. C. Ferreira, S. Han, A. Boam, S. Zhang and A. G. Livingston, "Membrane Aromatic Recovery System (MARS): Lab Bench to Industrial Pilot Scale,” Desalination, Vol. 148, No. 1-3, 2002, pp. 267-273. doi:10.1016/S0011-9164(02)00709-9

[16] “Kagaku Daijiten,” Kyoritsu Shuppan, Tokyo, 1963, p.
447.

[17] J. Hur, J. P. O’Connell, K. K. Bae, K. S. Kang and J. W. Kang," Measurements and Correlation of Solid-Liquid Equilibria of the $\mathrm{HI}+\mathrm{I}_{2}+\mathrm{H}_{2} \mathrm{O}$ System," Internatinal Journal of Hydrogen Energy, Vol. 36, No. 14, 2011, pp. 8187-8191. doi:10.1016/j.ijhydene.2011.04.125

[18] N. Watanabe and T. Miyauchi, "The Permeation of Iodine through a Diaphragm Type Liquid Membrane-The Diffusion Coefficient of Iodine in Poly (Dimethylsiloxane)," Kagaku Kogaku Ronbunshu, Vol. 2, No. 3, 1976, pp. 262265. (In Japanese) doi:10.1252/kakoronbunshu.2.262

[19] M. Imai, S. Furisaki and T. Miyauchi, "Separation of Volatile Materials by Gas Membrane,” Industrial \& Engineering Chemistry Process Design and Research, Vol. 21, No. 3, 1982, pp. 421-426. doi:10.1021/i200018a013

[20] N. Watanabe and T. Miyauchi, "Determination of Solubility Parameter For Siloxane Segment,” Journal of Chemical Engineering of Japan, Vol. 6, No. 2, 1973, pp. 109114. doi:10.1252/jcej.6.109

[21] S. C. George, M. Knorgen and S. Thomas, "Effect of Nature and Extent Cross-Linking on Swelling and Mechanical Behavior of Styrene-Butadiene Rubber Membrane,” Journal of Membrane Science, Vol. 163, No. 1, 1999, pp. 1-17. doi:10.1016/S0376-7388(99)00098-8

[22] S. Han, F. C. Ferreira and A. G. Livingston, "Membrane Aromatic Recovery System (MARS)—A New Membrane Process for the Recovery of Phenols from Wastewaters," Journal of Membrane Science, Vol. 188, No. 1-3, 2001, pp. 219-233. doi:10.1016/S0376-7388(01)00377-5

[23] K. C. Farinas, L. Doh, S. Venkatramann and R. O. Potts, "Characterization of Solute Diffusion in a Polymer Using ATR-FTIR Spectroscopy and Bulk Transport Techniques," Macromolecules, Vol. 27, No. 18, 1994, pp. 5220-5222. doi:10.1021/ma00096a055 